\title{
Oksana Konik
}

Senior lecturer

Crimean University for the Humanities

\section{BILINGUAL ASPECTS OF FUTURE PHILOLOGISTS PROFESSIONAL TRAINING}

\begin{abstract}
The article highlights the problem of professional preparation of future language teachers. The author determines varieties of bilingualism and their impact on the system of teacher training. The notion of bilingual education is given. The models and conceptions of bilingual education are analysed.
\end{abstract}

In today's world languages play an important role. Knowledge of a foreign language opens up opportunities for a person: acquainting with new people and visiting new countries and constant expansion of horizons, as well as strengthening economic, political and cultural ties between different countries. In connection with this feature of the modern society and culture multilingualism is the most common form. Bilingualism is knowledge of two languages and their alternation depending on the use of the environment of the speech communication" [Weinreich, 1972, p. 25].

According to the method of second language acquisition there are two types of bilingualism: natural and artificial. Natural bilingualism is seen as mastering a second language primarily innatural environment along with their native language (for example, as a result of conquests, migrations of peoples and peaceful contacts between neighboring multi-lingual groups). Artificial bilingualism - the study of one or more foreign languages in an organized form given by an institution. Artificial situation of bilingualism, bilingual education is seen from the point of the twentieth century as one of the leadingareas of the educational policy of the European countries. Many countries provide bilingual education in schools and in higher educational institutions. Of particular interest it is when considered as a necessary component of the 
contents of the training of future professionals, including teachers of foreign languages.

In a situation of artificial bilingualism in teaching foreign languages, one cannot forget that bilingualism is a multifaceted phenomenon, including the linguistic, cultural, psychological, sociological characteristics. Clearly, trainingof foreign language teachers includes linguistic factors as a specialist must acquire at least two languages - native and foreign.It is not enough to know one or the other language with only phonetic, grammatical and lexical point of view. In the speech of a man who speaks several languages, there is not only the interaction of language systems but the presence of various ones. Therefore, the aim of bilingual education should also be the comprehension of culture of the partner country, students' tolerance, desire for understanding of other people, their characteristics and traditions.

An introduction to a different culture is not only to give students facts about the culture, above all, he must be able to navigate it (to carry out cultural practices in Germany, Switzerland or the United Kingdom, the United States of America, even if he has never been in this country). This means that future philologists need to be able to use a different culture, that is, its own laws of functioning.We should not forget also that bilingualism does not imply biculturality automatically because you can own to varying degrees two languages, that belong to the same culture. Bilingual education may or may not lead to biculturality, which depends largely on the intentions of eachspecific individual learner, and the nature of the bilingualeducation policy. Therefore, great care must be given to the content of the educational program: for example, in higherschools the discipline of linguistic country study must be taught, as well meetings with native speakers, a variety of seminars, parties, etc. are to be organized. It would be nice if instructural unit of the university they turned to invite to work at least one representative of another country.

Bilingual education should be understood as a purposeful process of initiation to the world by means of the native culture and a foreign language, a foreign language acts here as a way of understanding the world, the acquisition of specialized knowledge, learningcultural, historical and social experience of different countries andpeoples.

But the question is how to achieve the best effectwhen learning a foreign language: to use in the classroom and at home a foreign language only. In the scientific literature 
scholarshas not yet come to a consensus on the use ofthe native language in the classroom in a foreign language. Some believe that the use of the foreign language leads to the early formation of foreign language communicative competence. Others, on the contrary, are calling for the use of the native language in the classroom. Lack of opportunities to use the languagecan lead to confusion, misunderstanding, misinterpretation of the facts and realities of the culture.The majority of linguists are inclined to the view that the assimilation of the second (foreign) language goes in stages, and each stage involves the use of native and foreign language, but in different proportions. For example, one of the concepts of domestic bilingual education is the following steps or models of bilingual (bicultural) education:

1) backup model (typically, the initial training provides presentation of the same units of content in native and foreign languages. This model contributes to the accumulation of linguistic tools that can adequately express the subject content. In this model, the individual learner establishes stable associative relationship between the unit and a set of meaningful language means);

2) the additive model (it assumes the presentation of a foreign language additional information partially or substantially en- riching the content learned in their native language. Additional information is generally retrieved from sources of foreign languages andis presented as a story of the teacher, the printed text of a special didactic material (movies, audio, etc.). A comparison and discussion of the primary and secondary meaningful units are done in a mother and a foreign languages);

3) Parity model (it assumes equitable use of native and foreign languages in the disclosure of subject content. A necessary condition for the use of this model is that learners achieve a sufficiently high level of language competence. This meansthe knowledge oftechnical terms, the main conceptual possession of sufficientdevice objects, the ability to detect nuances of meaning, especiallythe use of technical terms), and

4) displacing model (foreign language plays dominant role in the disclosure of subject content.The use of this model is possible only at an advanced level of bilingual education, because students must possess a foreign language to the freeextent to carry out communication and foreign language means to penetrate deeply intosubject content. Implementation of this model is possible, such active forms and methods such as discussion, debate methods, projects, etc. are used) [Shirin, 2005, p. 63]. 
Obviously, during the first two stages of learning a foreign language dominant role in the speech of bilingual will play their native language (the language thinking). From this it follows that the bilingual has not yet learned enougha second language system, and it is subject to the same mechanisms of the native language. At subsequent stages of learning the relationship between foreign language skills in their native and in a foreign language are equalized as fluent bilingual both language systems. It seems that in the higher education institutions the departments of foreign languages should propound parity and preemptive model of learning.

In addition, bilingual education is not only for students, but also for teachers. For the successful implementation of the concept of bilingual education preparation of professionals who should, in our opinion, have a multilateral competence becomes important. Competence of teachers should include

not only subject matter, language, but also the general pedagogical (didactic, communicative, organizational skills) competence, the importance of which is often underestimated. The teacher must be able to adapt subject content in a foreign language to the peculiarities of national educational culture. Such experts in multilateral competence are to work in higher education.

Undoubtedly, bilingual education in the countryto be effective, it must be conducted not only in higher education institutions, but in schools as well as kindergartens. Furthermore, bilingual education should take into account such organizational didactic features such as: 1) the choice of language of instruction, and 2) the optimal selection of the content of the educational programs, and 3) membership of teachersin an ethnic group or their competence in the relevant language and culture, and some others. With this policy bilingual education can significantly expand the overall outlook of students, promote their intellectual development in the mastery of a foreign language. This means learning the language of new strata of culture, othersocial and historical patterns. Foreign language will be, above all, the educational value that extends the range of further educational and professional opportunities of the graduates, including the future of foreign language teachers. 


\section{References:}

1. Weinreich U. Monolingualism and multilingualism / U. Weinreich / / New in Linguistics. - Moscow, 1972. - Issue. 6: Language contacts. - S. 25-60.

2. Shirin A. G. Didactic and methodological aspects of the process of Bilingual Education /A.G.Shirin. - Bulletin of the NovgorodState University. - 2005. - № 31. - S. 63-66. 